Prifysgol Cymru

Y Drindod Dewi Sant

University of Wales

Trinity Saint David

\section{Cadwrfa Ymchwil Research Repository}

Teitl - Title: Exploring Aredhiou: New Light on the Rural Communities of the Cypriot Hinterland during the Late Bronze Age

Awdur - Author: Dr Louise Steel

Blwyddyn - Year: 2016

Manlyion Cyswllt yr Awdur - Author Contact Details: 1.steel@uwtsd.ac.uk

http://repository.uwtsd.ac.uk repository@uwtsd.ac.uk 


\title{
Exploring Aredhiou: New Light on the Rural Communities of the Cypriot Hinterland during the Late Bronze Age
}

\begin{abstract}
$\underline{\text { Abstract }}$
This paper explores social practices and the material world at Aredhiou Vouppes, a Late Bronze Age rural community in the Cypriot hinterland. In-depth analysis of the excavation results demonstrates that this site was more complex than current typologies of inland production centres, based mainly on survey data, would suggest. Instead it was multi-functional and played an important economic role within the wider Cypriot landscape. This paper explores the evidence for initial occupation at Aredhiou during MC III-LC I, but the main focus is on the substantial LC IIC remains. Through a detailed contextual analysis, and the identification of a multiplicity of activities practiced at the site, it examines social practice, gender relations and ritual performance within a small farming community."
\end{abstract}

\section{INTRODUCTION}

The Late Bronze Age on Cyprus (ca. 1650-1050 BC, table 1) is characterized by significant social and economic changes associated with the emergence of urban communities along the coastal strip, formation and monumentalization of the urban landscape, intensification of production (especially of copper), the appearance of nascent administrative economies and increasing participation in international maritime trade. ${ }^{1}$ There is evidence that some individuals were involved in diplomatic gift exchanges with the Egyptian pharaohs at least during the late $18^{\text {th }}$ Dynasty. ${ }^{2}$ All of these archaeological phenomena represent significant changes in the daily experience of the island's inhabitants, their social practices within the household, their production base and the organization of their communities. The strategies employed by emergent elite groups - who through their control of agricultural resources, the growing demand 
for Cypriot copper and maritime trade, were increasingly able to manipulate the social, ideological and political landscape - have been extensively discussed in the literature. The changing social and material worlds of the average Late Bronze Age Cypriot however, have received less attention. ${ }^{3}$ This is in stark contrast to the very much more socialized picture archaeologists have developed for the preceding Early-Middle Cypriot (EC-MC) periods, in particular the extensive discussion of household activities. ${ }^{4}$ Instead, there has been considerable emphasis on trying to assess the level of Late Cypriot (LC) socio-political organization according to anthropologically derived models. ${ }^{5}$

The focus of this paper is social practice within a rural community in the Cypriot hinterland, Aredhiou Vouppes, with an aim of exploring the habitus and material experiences of its inhabitants. Other than survey of Analiondas Palioklichia ${ }^{6}$ and the excavation of a supposed sanctuary at Ayia Irini, ${ }^{7}$ these inland farming communities have been largely unstudied. Even so, they form the lynchpin of the various models of complex settlement hierarchy (fig. 1) that have been put forward for the LC II period, according to site size, location, and material remains. ${ }^{8}$ Originally Hector Catling ${ }^{9}$ proposed a three-tiered model, comprising the coastal urban centers that have been extensively explored in various excavations, inland agricultural settlements such as Aredhiou, and copper production centers. Priscilla Keswani ${ }^{10}$ has argued that these settlements co-existed within a nexus of regional exchanges of wealth and staple finance, the interior effectively providing foodstuffs and other resources to support the coastal towns. Bernard Knapp ${ }^{11}$ has proposed a refined four-tiered model, which takes into consideration the diversity of settlement type identified within the interior. At the apex of this hierarchy are the large urban centers located in the coastal plains. Inhabitants of these towns were involved in maritime trade with the Aegean, Egypt and the Levant; there is also evidence for some centralized administration, monumental religious buildings and some industrial 
activity. Examples include Enkomi, Hala Sultan Tekke, Kalavasos Ayios Dhimitrios and Episkopi Bamboula. Within the hinterland Knapp identifies a further three levels in the settlement hierarchy. The second level comprises inland towns, with evidence for a variety of activities (administrative, production, transport, and some storage), for example Pyla Kokkinokremos. In addition he categorizes a tertiary level, comprising smaller inland sites which are primarily religious, but also with some production and storage activities, such as Myrtou Pigadhes and Athienou Pamboulari tis Koukounninas. At the base of the settlement hierarchy Knapp places various specialized production sites: agricultural sites such as Aredhiou Vouppes, mining sites such as Apliki Karamallos and Politiko Phorades, and industrial sites such as Sanidha Moutti tou Ayiou Serkhou, involved in specialized pottery production.

While this paper broadly adheres to Knapp's four-tiered settlement model, analysis of the excavations at Aredhiou indicates that the designation of the inland production sites requires some refinement. The excavated material from Aredhiou demonstrates that the posited agricultural sites were far more complex than the current typology, which for the most part is based on survey data, would suggest. Instead these sites were multi-functional and played an important economic role within the wider Cypriot landscape. This paper explores the evidence for initial activity at Aredhiou in MC III-LC I, which is seen as part of the increasing exploitation of the island's metalliferous zone during this period. The main focus, however, is the substantial LC IIC remains; contextual analyses reveal significant information relating to the range of activities practiced at the site during this period, opening a whole new window on the social practices of the LC community at Aredhiou.

\section{HOUSEHOLD AND COMMUNITY}


As described so evocatively by Ruth Tringham, ${ }^{12}$ it is difficult to envisage the inhabitants of archaeological sites as any more than "a lot of faceless blobs", and the social relations and lifeways experienced by ancient peoples remain elusive within the archaeological record. Nonetheless, this paper sets out to "people" the settlement at Aredhiou and animate Tringham's "faceless blobs" by considering the structures and activities identified at the site from the perspectives of the household ${ }^{13}$ and the community. ${ }^{14}$

The household underpins social interaction at many levels. Individuals (social actors) become culturally informed beings at the hearth: ${ }^{15}$ learning a range of cultural practices, including language, subsistence strategies and technologies, traditions and ideologies, and through this their habitus, they develop their own unique sense of identity (as individuals, members of the household and members of the wider community). As such the household is more than the material remains of ancient dwellings and the residues of activities (food processing, cooking, pottery and tool production to name but a few) enacted therein. It is the social hub where children learn and develop into fully functioning members of the community and in which knowledge is disseminated through the generations, as members of the household commune around the hearth exchanging knowledge, ideas, gossip and stories on a daily basis. A community might be defined as a group of individuals or households with a common residential base, shared (cultural) experiences, and shared identities. ${ }^{16}$ Social relations are performed and recreated within the community on a daily basis and as such it forms the wider arena for social reproduction. Consequently, communities are more than the residual remains of residential nucleation and specific patterns of activities and material culture within the archaeological record; instead they are "a dynamic and complex social institution", ${ }^{17}$ in which social relations are continually reiterated, reinforced and renegotiated through specific actions on the part of socialized individuals. ${ }^{18}$ Archaeologists, however, are left with "abandoned and/or destroyed 
sites ... the way life ended in a community", ${ }^{19}$ and the challenge lies in inferring daily life and the repeated activities which form the core of a community's habitus from the excavated remains. $^{20}$

At Aredhiou we used the Museum of London single context recording system ${ }^{21}$ which allows for a detailed analysis of the finds according to context and specifically the distinction between sealed deposits on floors and the accumulation of fill above these. "In the main, it is only the latest or final use and abandonment episodes that preserve assemblages closely related to room or area function and activity";22 the problem we faced was determining what material formed the residue of activities within the different rooms, courtyards and other work spaces identified and materials which ended up in a context as a result of other taxonomic processes, or perhaps simply representing background noise. David Frankel and Jennifer Webb suggest that the distinction between ad-hoc and curated tools is one means of distinguishing between different types of formation episodes; ${ }^{23}$ in addition we considered the completeness or otherwise of the deposit, in particular whether or not there were restorable vessels amongst the sherdage; the depth of deposit sealing a context; and whether we could identify the results of conscious, deliberate action in the creation of a deposit, as for example a foundation deposit.

\section{AREDHIOU VOUPPES (LITHOSOUROS)}

The site of Aredhiou Vouppes (fig. 2) was first identified in survey by the Sydney-Cyprus Survey Project (SCSP) in $1993 .{ }^{24}$ Although it has become known to the archaeological community as Aredhiou Vouppes the local name is in fact Lithosouros, meaning "mound of stones". ${ }^{25}$ The site lies at the interface between the fertile Mesaoria plain, which was probably heavily forested in antiquity, and the foothills of the Troodos massif. Aredhiou was initially ranked with other small production sites of the hinterland (mining, pottery, agricultural), 
specifically as an agricultural production centre, on the basis of the surface finds, namely the high frequency of ground stone tools and pithos sherds. ${ }^{26}$ According to the current settlement hierarchy, such sites provided agricultural surplus to support mining communities in the agriculturally non-productive lower slopes of the Troodos Massif, and possibly likewise for the coastal towns. ${ }^{27}$ However, it has also been suggested that they are subsidiary to larger inland settlements, the latter which functioned as an economic intermediary between the production sites of the interior and the coastal towns. The current model posits that these secondary/tertiary sites acted as communication nodes for redistribution of agricultural surplus and the movement of semi-processed copper. ${ }^{28}$

A team from the University of Wales Lampeter has completed five seasons of fieldwork at Aredhiou, the results of which have allowed us to refine and develop our interpretation of the site. ${ }^{29}$ Firstly, it is worth noting that the extent of Late Bronze Age activity at Aredhiou is greater than initially thought. In addition to the two hectares originally identified and surveyed by SCSP, we have also surveyed the field systems immediately to the north, across which we consistently recovered Late Bronze Age material, including a possible Late Minoan (LM) IIIB stirrup jar handle in with an incised Cypro-Minoan sign. ${ }^{30}$ Moreover, LC material, including a fine example of a gaming stone (fig. 3), has been recovered in fields 500m north of the main site. These are associated with possible Bronze Age walls eroding out from the scarp at the edge of the field (fig. 4). While the spread of material might suggest a site of some size - possibly as large as ten hectares, which is close to the size suggested for some of the coastal urban centers present evidence indicates dispersed scatters of activity, rather than a large planned and gridded complex over the full extent of the site. The full extent of the site is impossible to determine however, as extensive terracing and more recent leveling associated with intensive modern farming practices have removed much of the archaeological deposits down to bedrock. 
Pithoi are predominant amongst the LC pottery recovered during intensive survey, ${ }^{31}$ primarily from smaller, short-necked pithoi; in addition there are local reports of a row of storage pithoi found during construction of the main agricultural building at the site. These Keswani suggests were used for short-term storage of foodstuffs that were accessed on a regular basis. ${ }^{32}$ Another striking aspect of continued field-walking over the site is the large volume of ground stone tools, including numerous rubbers, grinders, polishers, hammerstones and several querns. A limestone basin fragment, ${ }^{33}$ with parallels at another inland agricultural settlement at Analiondas Palioklichia, ${ }^{34}$ was possibly used in the processing of agricultural produce. In addition to the ground stone identified in survey, local farmers report literally cartloads of worked stones being removed from the site over the past 50 years. This material is likely to represent continuous processing of agricultural produce by members of the community over a long period of time. Furthermore, occasional anvils, ${ }^{35}$ including a broken quern re-used as an anvil, illustrate some metallurgical activity at the site (fig. 5).

\section{EARLY OCCUPATION AT AREDHIOU: MC III-LC I COMMUNITY}

The main phase of occupation at Aredhiou dates to the LC IIC period (13 ${ }^{\text {th }}$ century B.C.E.); at present there is no clear evidence that activity at the site continued into LC IIIA, although there is some evidence for discrete pockets of Early Iron Age activity. ${ }^{36}$ There is, moreover, significant evidence for an early phase of occupation at Aredhiou, in MC III-LC I (c. 1750/1700-1400 B.C.E.). Survey material included quantities of LC I pottery; ${ }^{37}$ and small quantities of Red Polished and LC I pottery also occur in excavated contexts, apparently background noise from the earliest occupation at the site. The community represented by these finds remains enigmatic; to date there is limited evidence if any of their living space and only residual remains of their activities. Indeed, the fragmentary pottery represents the only window 
into the daily life and household experiences of this early community. Amongst the pottery there are occasional Plain White Handmade sherds from storage jars, ${ }^{38}$ paralleled by those from MC III-LC I settlements such as Kalopsidha, ${ }^{39}$ and tomb groups at Palaeoskoutella, Galinorporni and Lapithos. ${ }^{40}$ These suggest a small farming household storing agricultural produce for its own subsistence needs. The presence of this ware also demonstrates that the early community at Aredhiou was aware of developments in ceramic technology and social behavior current in Eastern Cyprus, in particular within the emergent urban community of Enkomi, and was also influenced by knowledge of Levantine practices of ceramic production. ${ }^{41}$ The earliest occupants not only continued to use Red Polished bowls within the household, but also had access to the new Monochrome, Base Ring I and White Slip I wares, and occasionally even Red on Black vessels, which were produced at Phlamoudhi Melissa and used in ceremonial feasting at sites along the north coast and Karpass peninsula, most notably at Phlamoudhi Vounari. ${ }^{42}$ The pottery record also indicates that Black Slip and Red Slip (both hand and wheelmade) were frequently used by this early community: the quantities of both wares, attested in survey ${ }^{43}$ and excavation, suggest they were used on a daily basis within the household and consequently were frequently broken, thus entering the archaeological record in some quantity. A tantalizing picture therefore is emerging of a small, self-sufficient community at Aredhiou, perhaps geographically isolated, but certainly with access to the latest modes of household and ritual consumption prevalent in eastern Cyprus and along the north coast.

Although the evidence is somewhat limited, we might make some inferences as to the type of household or community represented by this fragmentary pottery through analogy with contemporary settlements; however, the archaeological evidence for the MC III-LC I occupation remains sporadic. While the most comprehensive record for this period is provided by the area of the so-called fortress at Enkomi, perhaps the single-building settlement at 
Kalopsidha provides a better analogy. Here Einar Gjerstad identified the remains of a freestanding, multi-roomed structure built around a courtyard. ${ }^{44}$ Diane Bolger suggests that the arrangement of space at Kalopsidha reflects major changes in the organization of the household and the practice of domestic activities at the transitional Middle-Late Bronze Age, ${ }^{45}$ representing a shift away from shared, communal interaction towards a privatization of labor perhaps associated with an emerging unit of the nuclear family. A more recent assessment of the architecture, however, suggests that rather than a free-standing structure the Kalopsidha house in fact corresponded with the courtyard house compounds identified at Marki Alonia in the MC III levels. ${ }^{46}$

Limited MC III-LC I occupation at Aredhiou is further reiterated by the tomb group excavated in 2006; amongst the grave goods were a Black Slip wheelmade jug (fig. 6) and a fine hooktanged bronze spear. ${ }^{47}$ The jug is intriguing for its continued, archaizing use of a round-base; in general flat bases were preferred for the Black and Red Slip Wheelmade ware. ${ }^{48}$ This preference throws some light on the household choices made by the early community at Aredhiou, specifically associated with changing practices in storing and serving liquids. ${ }^{49}$ The introduction of vessels with flat or ring bases suggests that these pots were intended to be placed on a flat surface, perhaps indicative of dining around the table. For the individuals using these new vessels this might suggest "a radically different engagement with the physical, material world which undoubtedly affected social relations within the Cypriot household". ${ }^{50}$ At Aredhiou however, we might posit some cultural conservatism at least in the practices surrounding the serving and consumption of liquids.

The spear (fig. 7) indicates the early burial phase was of an individual (or family) of some importance and wealth within the local community. Other wealthy MC-LC tombs have been 
identified in the nearby area, around Politiko village, furnished with metal weaponry and other status goods. ${ }^{51}$ In contrast to these sites however, there is no evidence that individuals at Aredhiou either had access to imported Levantine luxuries or chose to place them in their tombs, although it should be emphasized that the tomb had been looted (indeed almost emptied out) in antiquity. The early community at Aredhiou therefore can be placed within a wider socio-economic framework, as one of a number of wealthy tombs in the central copper production zone. It is usually agreed that the emergent elites of this region acquired access to such wealth through control over copper resources and chose to exhibit it in their mortuary display. Certainly, Aredhiou is well placed in this respect; in addition to the contemporary LC I copper extraction site at Politiko Phorades, SCSP identified several other ancient copper production locales in the immediate vicinity. Therefore we might envisage a small community, possibly even only a handful of households, at Aredhiou in MC III-LC I whose inhabitants had access to prestige goods and an interest in copper extraction. This community may well have acted as an intermediary between small mining communities such as Phorades $^{52}$ and the emergent coastal towns, such as Enkomi ${ }^{53}$ and Morphou Toumba tou Skourou, ${ }^{54}$ in response to external demand for Cypriot copper. ${ }^{55}$ Plausibly, the relationship between mining communities and farming settlements posited for the LC II period was already developing in the formative stages of the Late Bronze Age. Given significant surface pottery of this date, a key future research aim would be to identify some settlement remains - assuming these had not been leveled either to make way for the later, $13^{\text {th }}$ century B.C.E. occupation, or more recently in terracing and agricultural activity.

\section{LC IIC OCCUPATION AT AREDHIOU}

Excavation has uncovered significant evidence for the LC IIC activity at Aredhiou. ${ }^{56}$ Although the preservation of architectural remains across the excavated areas is fragmentary, two main 
buildings and several walls (which at present cannot be resolved into a meaningful plan) have been identified. These were all built on the same alignment, slightly off the North - South axis. Present evidence suggests that these buildings do not form part of a continuous planned grid over the site; instead the site was subdivided into discrete activity zones, at some distance from each other. Although we have yet to identify and excavate domestic, residential buildings, the massive architecture and the variety of associated activities are suggestive of a reasonably-sized and well-organized community. ${ }^{57}$ The absence of household remains is most probably a result of the degradation of archaeological deposits across much of the site due to intensive terracing and agricultural activity. At present the funerary evidence is restricted to the eastern edge of the site. Tomb 1 was associated with badly robbed out walls; given the close association between domestic space and tombs at many LC settlements it is suggested that this was where the population of Aredhiou resided and buried their dead.

Seasonality of activity is certainly an important question to consider, in particular given the apparent link between Aredhiou and the surrounding mining communities. One possibility we might explore is whether members of the community worked in the mines during the summer months, returning to Aredhiou to complete agricultural activities over the autumn, winter and spring months. It has been argued that seasonal mining was common in ancient mining communities, performed for the most part by individuals drawn from agricultural communities during the months when they were unable to farm their fields. ${ }^{58}$ The material remains demonstrate some connectivity between Aredhiou and the nearby mines, although there is no actual evidence for metal-working itself at the site: several of the ground stone tools are of types commonly associated with copper-working at sites such as Apliki, and I would suggest that these were valued and curated objects which were brought back to Aredhiou for storage when not in use ${ }^{59}$ moreover, around $10 \mathrm{~kg}$ of copper slag has been found in association with Building 
1, where it was incorporated within the built environment (discussed below). ${ }^{60}$ Other seasonal occupations might include pottery production and possible procurement of clay and other resources over some distance, ${ }^{61}$ and other specialist craft activities. Most of the pottery conforms to LC standards and was presumably imported into the site from production centers elsewhere on the island; however, the pithoi and possibly also the Plain ware demonstrate some local idiosyncrasies in terms of fabric and some decoration which might illustrate local production. ${ }^{62}$ The social consequences of the implied labor migration certainly would have had a significant impact on the community at Aredhiou not least upon gender relations. ${ }^{63}$

Buildings 1 and 2 have been the main focus of excavation; ${ }^{64}$ neither building conforms to the range of known Late Bronze Age buildings on Cyprus in terms of their architectural layout and some of the architectural practices. Moreover, detailed examination of the architecture suggests careful building construction rather than the rude or rustic architecture that might possibly have been expected from a small farming settlement. Except in a few places, the architecture does not survive above the lowest course of stones. The building material for the most part comprises large diabase pebbles procured from the adjacent Aloupos riverbed - but on occasion other more distinctive stones are used. The main entrance into Building 1 (fig. 8) is elaborated, a large igneous stone was used as a quoin and large white pebbles were embedded into the floor to mark the threshold - both stones are intrusive to the site and were brought from some distance. Likewise, in certain work areas sedimentary stone slabs are used to create flat emplacements; this is seen in a work area in the southern courtyard of Building 1, a low stone bench/platform abutting the southern wall of the portico of Building 1, and around the well in Building $2 .{ }^{65}$ Local information suggests that these stones were procured over a distance of several kilometers. Clearly some effort was expended in construction at the site - the care in architecture is particularly evident in Building 2 (fig. 9). Unlike the more typical Bronze Age 
architecture attested on the site it is totally rectilinear and only consists of right-angles; this applies to the outside wall, internal partition and the southern wall of the courtyard. The building demonstrates careful, well thought out planning; the demonstrable importance of this building to the community at Aredhiou is reiterated by the occurrence of a foundation deposit in the southern wall - the only one attested on site to date.

\section{IDENTIFICATION OF ACTIVITY AREAS}

One of the key outcomes of excavation has been an understanding of the multiplicity of activities represented at Aredhiou. These are organized within discrete activity zones and in contrast to current understanding of LC urban areas were housed within communal buildings rather than within separate households. ${ }^{66}$ The activities practiced at the site can only be inferred from the material remains. ${ }^{67}$ The predominance of pithoi and ground stone tools found in the survey are the basis of the site's identification as an agricultural centre ${ }^{68}$ but the pottery and other finds recovered in excavation reveal a more complex web of social and economic interactions: in addition to farming, storage and processing of foodstuffs, there is limited evidence for animal herding, textile production, and food consumption - namely the range of activities we might expect in any Bronze Age household. Moreover, the community at Aredhiou was embedded in economic ties with, and beyond, the coastal urban communities, as is indicated by imported pottery from Egypt, the Aegean and the Levant. How these objects were incorporated within social practices at the site is the focus of ongoing research. ${ }^{69}$

\section{Building 2}

There is some evidence for control over specific resources at Aredhiou, most notably water. The site was well positioned in antiquity for access to water resources, lying on the eastern side of the Aloupos River. There is no way at present to assess the nature and extent to which this 
resource was being exploited by the community at Aredhiou; however, we might suggest that collection of water from the river would have been a gendered communal activity, one which ethnographic analogy and reference to ancient sources indicate to be a female task. ${ }^{70}$ There was however, some perceived need for access to water within the limits of the settlement, as demonstrated by the construction of a well, located within the southern room of Building 2 . The well is typical of the LC period: the upper meter was lined with stone, and a fine stone emplacement was constructed around its opening. The location of the well within a small room is also paralleled elsewhere on the island - no doubt the need for clean water necessitated some covering of the well to keep animals out. Unusually, the well yielded few finds. Only fourteen sherds and a large quern were recovered from the fill, from which we might surmise that the receptacles used to draw water were made from perishable materials; moreover it was not reused for rubbish disposal, unlike wells in the urban centers. ${ }^{71}$ Significantly, most of the sherds from the well appear to be from drinking vessels associated with the earliest (MCIII-LC I) phase of activity at the site, which might indicate its initial construction and use during this period; nonetheless, given the very limited quantities of pottery recovered, and its fragmented state, it would perhaps be unwise to draw too many conclusions from this material.

Another striking aspect is the apparent control exercised over access to the well. The room in which it was located (fig. 10) was only small enough for a single individual to draw up water and the entrance into the room was similarly only large enough for a single person to enter/leave at a time. Moreover, the southern wall of the adjacent courtyard restricted access into the well room from the southern work area of the site. This picture of water procurement gives us an insight into the daily activities of the community at Aredhiou - one which is discordant to our understanding of the communal collection of water in other cultures, and which emphasizes the importance of this resource to the community at Aredhiou. This apparent control over water 
resources might reflect practices in other LC communities - certainly, Bolger has argued that water resources become more privatized during the $\mathrm{LBA}^{72}$ - but these changing cultural values were not embedded in all LC settlements. In the urban communities of Hala Sultan Tekke and Episkopi Bamboula for example, there was communal access to wells. ${ }^{73}$ The importance of water to the activities probably carried out in the courtyard of Building 2 is further reiterated by the nature of a possible foundation deposit, which comprises a near-complete water jug. ${ }^{74}$

The function of Building 2 remains elusive, particularly given the dearth of material recovered from the rooms, courtyard or adjacent open areas - although a fine example of a gaming stone was recovered from amongst the rubble collapse immediately to the south of the building. ${ }^{75}$ To the immediate north of the well room there were two long narrow rooms (96 and 208); these were open-ended with no return to the east or west walls at their north end. The resulting wide entrance was probably designed for ease of access allowing bulk movement of a commodity, no doubt facilitating access for pack animals and/or carts. Given the architectural properties we would suggest that Building 2 was a barn or warehouse - possibly for the storage of grain or straw. ${ }^{76}$ Being north-facing it seems evident that this was also intended to be kept cooler during the summer months. The surprising lack of pithoi found inside the building suggests that such storage was primary, straight from the fields. Possibly we are looking at the storage of fodder for donkeys and oxen, which would have played an important role in production and transportation of agricultural surplus and copper between the primary production sites of the hinterland and the coastal towns. Equally, we might consider the primary storage of food intended to serve as rations for workers in the copper mines or perhaps even to supply the towns. Furthermore, the investment in architecture, albeit not monumental, indicates the structure and its contents were of economic importance to the community at Aredhiou. It also seemingly indicates control over access and disbursement of its contents. The adjacent 
courtyard perhaps provided a sheltered place where animals could be contained, fed and watered, and where other tasks were undoubtedly completed, an aspect which we will consider in more depth in a discussion of gendered activities.

\section{Building 1}

Building 1 (fig. 11) is located some $25 \mathrm{~m}$ to the south of Building 2 and is built on the same alignment, suggestive of some form of organization of building activity at the site. This is a sizeable L-shaped structure with a substantial external wall, measuring $0.5 \mathrm{~m}$ thick, constructed from large diabase stones and other volcanic rocks. The size of Building 1 as extant, together with its massive construction, indicate it to be non-domestic; rather some form of public or communal building. This is reiterated by the range of materials recovered from the floor levels, which are "industrial" rather than domestic in character. The architectural arrangement and the distribution of artifacts indicate a variety of activities were performed in and around the building.

Our understanding of the architectural layout of Building 1 has altered significantly since initial publications of the remains excavated in $2006 .{ }^{77}$ Originally the remains were interpreted as a colonnaded portico area which abutted the main external southern and eastern walls, sheltering the main entrance. It was assumed that the portico was south facing and would have provided a shady area for activities during the summer, a sheltered area in which to work during the winter months, and a place where members of the community might gather. ${ }^{78}$ More detailed analyses of the plans and the associated finds however, revealed that the series of stone piers abutting the external walls of the building were in fact badly damaged walls, the footing of which had been largely removed through various taphonomic processes including recent plough activity. The 
tamped mud floor that had been interpreted as the external surface was extremely fragile and was worn away at roughly the same place that the walls disappeared.

Current understanding suggests Building 1 to be a $\Gamma$-shaped building - although the possibility of a series of rooms comprising a rectangular building, the south and east wings of which have been destroyed, should not be discounted. There is a substantial entranceway into the building at the northwest corner of the northern-most room (21). Immediately outside there was a substantial stone bench running along the southern part of the west wall. The massive external west wall of Building 1 and its elaborated entrance (discussed above) stand out from the extant architecture elsewhere at the site and perhaps illustrate significant community engagement in its construction. The badly damaged west wing comprises two square rooms (c.5 x 5m). A stone column base near the centre of room 21 indicates how the roof was supported. A well-worn quern was found upturned inside the doorway, ${ }^{79}$ together with a small quantity of slag and a very large stone pestle or pounder, ${ }^{80}$ similar to those from Apliki Karamallos. ${ }^{81}$ Plentiful broken pottery was found in deposits overlying the floor of the room and mixed in with the west wall (which only survives to one course in height). Joins between these sherds and a smaller number found directly on the surface belonged to a small number of semi-restorable vessels, including two Plain wheelmade bowls, two White Slip Bowls and a fragmentary cooking pot.

Three square rooms $(107,109$ and 161) delimited the northern wing of the building as extant. An apparently open area (106) to the south of room 109 and east of Room 21 had a tamped mud surface, the southern limits of which had been destroyed. That this area was integrated within the activities performed inside Building 1 is indicated by the flat stand carefully fashioned from sedimentary rocks, which abutted the southern wall of Building 1. Plain ware basin sherds were found in situ on this stand suggesting that it was been used for processing liquids. Just beyond 
the bench a work area was excavated in 2008 (Area 243/244): this comprised a surface of pebbles and slag set in mortar, associated with three large stones that had plausibly been used as anvils. ${ }^{82}$ The activities that took place in these rooms are elusive. While the quern might indicate food processing to be an important activity, its association with slag and the massive pounder are suggestive of other, "industrial" activities; indeed there is evidence from other LC sites that querns, pestle/pounders and other ground stone tools were used for processing metallurgical materials. ${ }^{83}$ Likewise, the pebble/slag surface was presumably primarily associated with heavy duty processing, or perhaps for processing liquids; certainly the basin stand/platform indicates that liquids played an important role in the activities performed here. The Canaanite jars were probably used to transport liquids to the basins, while the jugs were used to pour liquids into the bowls.

Immediately to the north of the main entrance there was an apparent work area (Area 75); this comprised a small pebble surface, a pit, and another series of flat sedimentary slabs set in a circular pattern. Associated finds include slag, a piece of chipped stone, some small copper/copper alloy trinkets, and fragmentary pottery. ${ }^{84}$ The slag was probably originally set into mortar to create a work surface, analogous to Area 243/244. Great care was taken in providing the work area with level surfaces, on which ceramic vessels and other objects could be placed securely. The fragmentary pottery primarily comprises Plain ware jugs and a large number of Cooking ware sherds which probably belonged to a two-handled globular pot. ${ }^{85} \mathrm{~A}$ large number of sherds were from White Slip II hemispherical bowls. Also noteworthy are three sherds from the same short-necked pithos with a wide mouth. ${ }^{86}$ The pit contained a large sherd from a globular cooking pot and some Plain ware and pithos sherds; while this certainly reflects the range of pottery from Area 75 there is no clear evidence that this material had been used there prior to deposition. The activities represented by this complement of pottery are unclear. 
To date there has been at most limited discussion of the function of the specific LC wares and forms; in a domestic context these are primarily assumed to be associated with storage, preparation and consumption of foodstuffs. We might suggest storage and processing of a liquid commodity; various possibilities include beer, ${ }^{87}$ wine, oil or milk products, which would need to be explored through a program of residue analysis. The work area was located in the southern limits of a large courtyard. ${ }^{88}$ Very few finds were found in situ in the courtyard, namely the complete neck of a Plain ware jug ${ }^{89}$ and a polished stone object originally identified as a pestle. Although the nature of activities that were performed in this space remains intangible we can infer that the north-facing, large open space provided a venue where numbers of individuals could gather together and engage in various communal tasks.

Two small rooms $(107,109)$ were excavated at the southern end of the courtyard. Low benches covered with the same flat slabs of sedimentary rock were built up against the north and west wall of room 109. A range of restorable utilitarian vessels, rarely found in such good preservation on LC sites, including Plain ware basins, jugs, a small pithos and a Monochrome ladle, together with and a variety of stone tools were found in room $109,{ }^{90}$ either in situ on the bench or broken in the associated building collapse. The small size of the two rooms indicates that the activities implied by this assemblage probably took place in the adjacent courtyard or nearby portico; rather workrooms 107 and 109 are more convincingly to be interpreted as storerooms or repositories. The complement of pottery is again suggestive of the processing of liquids, possibly associated with the activities in the nearby work area. The tools included a large stone hammer, a second tethering stone and a circular stone hammer, with parallels at Apliki Karamallos, Episkopi Phaneromeni and Kalavasos Ayios Dhimitrios..$^{91}$ The stone tools are indicative of a range of activities organized by the occupants of Building 1, but which probably occurred within the surrounding settlement and fields. 
Formalized discard practices were typical of LC sites; ceramics, in particular fine wares, were removed from living/working spaces and are frequently found deposited in latrines and wells. ${ }^{92}$ Pottery debris also tended to accumulate in outside areas, such as streets, drains, or against the walls of buildings; for example the pottery deposits recovered from the street running down the west side of Building X at Kalavasos Ayios Dhimitrios. ${ }^{93}$ Similar behavioral patterning is evident at Aredhiou with the accumulation of fragmentary pottery and other materials against the south side of Building 2. On the other hand, the density of pottery found on the floors of Building 1 (especially in room 21) contrasts with the majority of floor deposits at the site, which were remarkably free of debris. This is informative not only as to the life use of pottery in and around Building 1, but also how the community used and viewed this space. Rather than being kept clean and free of debris, broken pots had been allowed to accumulate here. Pottery is more likely to break, and thus enter the archaeological record in fragmentary form, when it is used repeatedly in a variety of activities. ${ }^{94}$ Thus, the density of pottery by the entrance to Building 1 indicates that this area was used regularly for various activities involving the processing and movement of liquids in utilitarian ceramic vessels.

To the west of the main group of rooms comprising Building 1 was an unusual sunken room (room 103), measuring c.7.5 x 5m; the floor level was around $1 \mathrm{~m}$ or so below the surrounding surface level of the adjacent buildings. It is unclear whether this belongs to the same structure or should be considered a separate, free-standing building. Here the builders had taken advantage of a substantial dip in the natural topography, possibly to create a cool, dark room for storage. We might expect that the room was illuminated to some extent by windows, as well as by lamps, the latter for which there is some evidence. Despite the depth of deposit no in situ remains were found on the floor; indeed the pottery found directly on the floor, and in the thick 
deposits of decayed mudbrick that sealed the floor level, was very fragmentary. The impression given is that the contents of the room were carefully retrieved by the occupants of Aredhiou when they abandoned the site. Even so, the range of pottery and other finds that were recovered from this room are suggestive of very different activities to those identified elsewhere on the site - distinct from storage, agricultural processing or metallurgy. Amongst the finds were several wall bracket fragments. These include a complete scoop (fig. 12) found in the upper fill adjacent to the southern wall, in situ from where it had fallen from the wall long after the building had been abandoned. Wall brackets are a common element of LC material culture, and are also found in the contemporary Levant and at Tiryns in the Argolid. Although their exact function remains unclear, they have most commonly been interpreted as lamps or incense burners and also as water scoops. ${ }^{95}$ Moreover, there is a growing consensus that these objects have some cultic or ritual significance ${ }^{96}$ and Roswitha Schlipphak has demonstrated their consistent occurrence in cult contexts in both Cyprus and the Levant. ${ }^{97}$ It should be noted however, that they are also found in domestic and metallurgical contexts ${ }^{98}-$ the former might relate to domestic cult, while the latter emphasizes the close links evident between craft production and cult in Late Bronze Age Cyprus. Following a detailed contextual analysis of Cypriot wall brackets, Dean Smith suggests that these objects in fact incorporated a varied range of cultural meanings and functions, although in many cases they were indeed an integral element of ceremonial performance. ${ }^{99}$ Further indications of a cult aspect to activities in room 103 include fragments of Base Ring bulls and a Plain ware horse figurine fragment.

The pottery sealed on the floor by $1 \mathrm{~m}$ of deposit was fragmentary and non-restorable, suggesting the room had been cleared prior to abandonment. The range and diversity of this material, as well as the debris mixed in with the mudbrick collapse sealing the floor deposit, is significantly different from that found elsewhere on the site and reiterates the special nature of 
room 103. There were no Plain ware basins, although Plain ware jugs were represented and a single Plain ware lamp sherd. It is interesting to note the combination of lamp and wall bracket in the same functional space, an association that has been noted elsewhere, such as Enkomi Levels IIIB and $\mathrm{C}^{100}$ and Pyla Kokkinokremos Complex B rooms 14 and 16 and Complex C, room 19. ${ }^{101}$ Presumably the sunken room, which had only one entrance at the south-west corner, would have been dark and consequently in need of lighting. The quantity of fine tableware stands out from the typical range of ceramic material throughout the site. Particularly noteworthy is presence of several rare and exotic wares: Minoan and Mycenaean imports, including one pictorial krater fragment, a Levantine platter bowl with string-cut base, and fragments from a Red Lustrous flask and White Shaved dipper juglet. There are also fragments from a Base Ring juglet and a Bucchero handmade jug.

Among the pottery from the fill overlying the floor is a second pictorial krater fragment. Certainly Minoan and Mycenaean krater fragments were used to mix wine in feasting rituals throughout the East Mediterranean. The wine was probably served using the dipper juglet, a mode of consumption adopted from Syrian cultural practices, best exemplified by a pictorial vase from Ugarit which depicts the god El drinking wine served from a krater using a dipper juglet. ${ }^{102}$ The kraters were typically placed on stands. ${ }^{103}$ Intriguingly, Philipp Stockhammer notes a consistent association of wall brackets and kraters in the Aegean (Tiryns room 8/00 in the Lower Town) ${ }^{104}$ and the Levant (Megiddo room 1817 and the Temple aux Rhytons, room 36 at Ugarit), ${ }^{105}$ the implication being that this complement of pottery was repeatedly used in feasting practices within a shared cultural milieu throughout the East Mediterranean. ${ }^{106}$ There was, nonetheless, significant cultural variation in the choice of drinking vessel throughout the region. ${ }^{107}$ At Aredhiou the preferred vessels for consuming wine were Mycenaean shallow bowls and their local imitations in the WPWM III ware; but the indigenous Base Ring carinated 
cup and White Slip hemispherical bowl are also represented. This range of drinking equipment conforms to the LC IIC norm elsewhere on the island.

The range of objects recovered in room 103 certainly suggests it played an important role in the ceremonial life of the community at Aredhiou. Its size and subterranean nature indicates that room 103 served for the gathering of a possible select and restricted group within the community. The lamp fragment and wall brackets suggest ceremonies staged within the darkened sunken room, perhaps accompanied by burning incense using the wall brackets ${ }^{108}$ and undoubtedly involving the consumption of alcohol (wine) served from a krater. Libations using the Base Ring bulls were another integral part of the ritual performance and we might equally envisage anointment with luxury unguents contained in the Red Lustrous flask. Indeed, residue analyses from a number of sites around the East Mediterranean illustrate that Red Lustrous flasks were typically used to transport and store plant-based oils, which were conceivably perfumed. ${ }^{109}$ Given the flasks' funerary associations in the Cypriot context ${ }^{110}$ a possible use for anointing the body has been inferred for their contents. ${ }^{111}$ The implied manipulation of the senses within an exclusive space no doubt played an important role in the embodied practices enacted within room 103, perhaps being used to foster a sense of identity and exclusivity, and manipulated to stage power relations within the wider community.

Building 1 therefore evidently housed a range of specialist, non-domestic activities. The stone tools and utilitarian wares indicate a range of processing activities, possibly of agricultural produce, which probably occurred within the portico and courtyard areas, while the subsidiary rooms were for storage of equipment. The copper slag demonstrates clear links with nearby mining sites and some limited metallurgical activity, which is further supported by certain tool types with parallels at Apliki. Discrete deposits of tableware might illustrate some communal 
consumption within this building, most notably within room 103, and possibly with some cultic aspect.

\section{WORKING ACTORS: GENDER AND PRODUCTION}

Initial archaeological studies which attempted to identify working highlighted the need to frame analyses within the ethnographic literature ${ }^{112}$ however we should be aware of the problems of indiscriminately applying ethnographic analogies unthinkingly to the archaeological record, in particular ascribing a task according to age/gender correlates and resulting essentialist narratives of male/female roles. As noted by Penelope Allison "the procedure should not be simply to use ethnographic data to describe household behaviour in the past but to use it also to highlight the potential for diversity and change"; ${ }^{113}$ as such and the following discussion is intended to draw attention to possible construction of gendered spaces through daily praxis at Aredhiou, informed by research on ancient and modern communities in the Mediterranean, rather than to paint an essentialist picture of male/female social roles. The allocation of tasks according to gender is well documented in both the ancient Near East ${ }^{114}$ and modern societies around the Mediterranean; ${ }^{115}$ thus the extent to which production activities at Aredhiou may have been structured along such gender divisions is a worthwhile line of enquiry, as is the identification of gendered space. Certainly, female and child labor is too significant an economic resource to be ignored, and we might indeed expect women and children to be engaged in many of the economic activities performed at the site, including working the fields, ${ }^{116}$ especially during the harvest. ${ }^{117}$ Moreover, if seasonality of the male labor force can be demonstrated then many household tasks and other activities would become wholly the responsibility of the women when the men left Aredhiou to work the copper mines. ${ }^{118}$ Similarly we might expect both children and older members of the community to contribute to economic production, as much as social reproduction. 
The LC community of Aredhiou is largely invisible to us, and the contemporary figurative repertoire is limited in scope for exploring social and economic action within the Late Bronze Age. Although, the scenic compositions on elaborate Red Polished funerary vessels belong to an earlier occupation of Cyprus, and thus might be significantly culturally removed from LC experience, these are informative as to the organization of household activities in the MC village communities and might provide some comparative data. According to recent interpretation of these scenes household activities were seemingly arranged along strict gender divisions with women performing domestic tasks, such as bread-making, grinding grain etc, while men tended the animals. ${ }^{119}$ Bolger attributes this gendered division of labor to agricultural intensification and the emergence of a nuclear household. ${ }^{120}$ Carol Meyers' discussion of agrarian communities in Iron Age Palestine likewise highlights two activities that are specifically associated with female workers: food production (primarily grinding cereals and baking bread) and textile production (spinning, weaving, and sewing for example). ${ }^{121}$ To these we might add archaeologically intangible activities, such as water procurement, basketry, ${ }^{122}$ basic maintenance of the household space including disposal of household debris, and childcare. Even though LC representational evidence is scarce a small number of object types help to furnish our understanding of female social/economic roles. A small number of LC II/III anthropomorphic bottles depicting women carrying water jars on their heads might serve to place water procurement within the female domain. ${ }^{123}$ Likewise, that child care (although not necessarily motherhood) was considered an important female social role is reiterated by the many "mother and child" representations common in MC and LC portable figurative art. ${ }^{124}$ The Red Polished vessels suggest many of these were communal activities in the MC villages. Similarly, Meyers suggests women from neighboring households worked together; not only sharing their workload and transmitting skills, but also engaging in important social interaction, 
gossiping, sharing social knowledge and cementing social ties. ${ }^{125}$ We might thus extrapolate this picture of shared activities beyond the household to the LC settlement at Aredhiou. Certainly the large, sheltered courtyard areas between the main buildings would provide appropriate areas for people to congregate and perform various tasks and activities together ${ }^{126}$ and we might envisage these as lively communal spaces.

Equally, it might be possible to identify carefully segregated gendered spaces, as has been suggested for several Bronze Age communities around the Mediterranean, based primarily on analyses of archaeological assemblages and inferred domestic activities; ${ }^{127}$ but we should also consider whether gendered space was dynamic, the same area being used differently by both men and women, perhaps alongside each other, perhaps at different times. ${ }^{128}$ In fact it is very difficult to interpret how domestic and public spaces were structured by LC communities, because these communities largely chose to keep their settlement area clean and free of the accumulated debris that we as archaeologists typically use to determine activity areas. ${ }^{129}$ Nonetheless, there are indications of gendered activities at Aredhiou. We have already discussed water procurement, presumably from the adjacent Aloupos River, as well as from the well in Building 2. Given the importance of this activity within the female domain, it is surprisingly missing from many gender studies of the East Mediterranean, ${ }^{130}$ due perhaps to its intangibility in the archaeological record. Notwithstanding, the collection of water provides women with an important social arena where "they exchange news and carry on their gossip". ${ }^{131}$ If we accept that collecting water from the well was a female task, we might interpret the adjacent courtyard area as a predominantly shady outdoor space where women gathered together, perhaps to gossip perhaps to work. This space no doubt also sheltered other activities. Noticeably, the artifacts recovered in and around Building 2 are largely associated with what we might consider to be women's work. A loom weight (fig. 13) and a small circular stone weight 
were found in soundings immediately south of Building 2, mixed in with what was predominantly "domestic" debris, comprising rich deposits of pottery and animal bone. Likewise, it is plausible that the quern found in the well was originally set in this area, perhaps related to the grinding of grain or other foodstuffs stored in the adjacent barn. While women might have been engaged in food-processing, collecting water and textile production, this common space was undoubtedly used by men "sequentially or in overlapping temporal units depending on the time of day, the season of the year, and the nature of tasks to be done", ${ }^{132}$ for example the bulk movement of cereals from the fields into the barn.

The presence of a well-preserved senet gaming stone (fig. 14) in the rubble tumble to the south of Building 2 might further enhance our understanding of gendered activity in and around this structure. While it seems probable that the gaming stone had in fact been deliberately built into the southern wall of the building, we should equally not ignore that this was an object with a biography, ${ }^{133}$ which was variously handled, perceived and incorporated within diverse social and embodied practices during its life-use, culminating in its incorporation within the built environment at Aredhiou. The cultural significance of this object is indicated by the unusually high incidence of gaming stones (for the Late Bronze Age) at the site. ${ }^{134}$ The exact function of gaming stones remains elusive; they are commonly identified as a local, "rustic" Cypriot version of the Egyptian game senet ${ }^{135}$ although there are alternative interpretations of a basic counting or calendrical device, ${ }^{136}$ which no doubt would have been of practical significance to a farming community. There is certainly no reason to preclude the recreational use of gaming stones - a significant number of which have now been discovered at Aredhiou - within a farming community; if we accept this identification then the gaming stones were interlinked within a complex network of socialized, embodied practices and cognitive actions. 
"The evident popularity of the game... and its widespread distribution in humble burials [in Egypt] proves it was not exclusively reserved for the literate minority. Common folk would posses Senet boards of wood, terracotta, stone, or could if necessary scoop out a series of holes in the ground"137

The question remains however, whether the apparent popularity of senet at Aredhiou informs us of gendered activities and recreational practices at the site. Certainly, within a modern context around the Aegean and East Mediterranean game playing (backgammon and chess) is almost exclusively a male pastime, particularly within the many kafenia found in these communities. ${ }^{138}$ Such a comparison suggests an additional and plausible use of the shaded courtyard area to the east of Building 2, this time by male actors.

\section{INTENTIONAL DEPOSITION}

Several recent archaeological studies have highlighted the diverse relationships that develop between people and their material worlds, focusing in particular on the entanglement of objects and people: as much as people do things to objects their actions are equally shaped by the agency of these objects. ${ }^{139}$ Objects are not bounded but instead they shift into new roles and meanings depending on how people choose to perceive and categorize them; they might be considered as having agency, ${ }^{140}$ thereby shaping the thoughts and actions of the individuals that use them. At Aredhiou some were deliberately incorporated into the fabric of the community, built into the foundations of walls and became part of the "the lived-in environment", where they continued to be interwoven within daily praxis.

The habitus of the communities and their culturally informed repeated actions frequently leave enigmatic traces in the archaeological record. Building 2 offers a fascinating insight into the ritualized actions of the inhabitants of Aredhiou through the intentional, structured deposition of 
certain objects that were deliberately removed from circulation, with no intention of recovery, and in some instances being incorporated into the built environment of the site. This structured deposition might well have been incorporated within some form of ceremony, although "nothing is implied about the scale or formality of the ritual, merely that it can be recognized as a practice distinct from the routine, taken-for-granted discard of refuse". ${ }^{141}$ In addition to the quern recovered from the well, and the gaming stone recovered from the rubble tumble to the south of the building there was also a second gaming stone intentionally built into the western wall of room $96^{142}$ and a foundation deposit beneath the southern wall of the building. ${ }^{143}$ Similarly, a gaming stone (also in fact a re-used rubber) was walled into the end room of Building $1 .{ }^{144}$ Although the context in which these objects were found suggests they were all deliberately removed from circulation, and as such might be considered as defunct or no longer functional, "[t]he deposition of artefacts did not necessarily mark the end of use-life but the beginning of a new phase in object biography; buried artefacts continued their life as a part of a place, the lived-in environment". ${ }^{145}$

Daily life at Aredhiou was mediated through numerous embodied and gendered practices involving querns, rubbers and other stone tools in a variety of economic and socialized actions. Consequently, these objects played an important role in the construction of identity, being associated with transformative practices and social reproduction. ${ }^{146}$ Consequently, the decision to remove a quern from its position of use and to deposit it within the well marks a significant event within the community. The quern from the well weighed a staggering $88 \mathrm{~kg}$; it demonstrated little sign of wear and to all intents was a pristine object with at most a short uselife prior to being thrown into the well and it would probably have taken two people to maneuver the quern into the room and to place it in the well. The significance of this action, how it related to the continued use or abandonment of Building 2, and the choice of object are 
enigmatic. One possibility is that the quern was an offering, one which was intrinsically associated with women, agricultural production and fertility, and which moreover reflected the investment of considerable time and skill to procure the raw material and fashion the quern.

A possible foundation deposit beneath the southern wall of Building 2 (fig. 15) comprises an incomplete Plain ware jug, perhaps broken intentionally. Foundation deposits are an ancient practice and are well attested throughout the ancient world, in Egypt, ${ }^{147}$ Mesopotamia ${ }^{148}$ and the Aegean. ${ }^{149}$ Typically, foundation deposits were placed beneath important buildings, such as temples and palaces, and comprised quantities of high status prestige objects fashioned in stone, metal or faience. ${ }^{150}$ They are commonly viewed as the material residue of ritual, ceremonial action, frequently associated with pouring of libations, hence the popularity of rhyta in Aegean contexts, ${ }^{151}$ and intended to commemorate the construction of these important buildings. Highstatus foundation deposits are rare on Cyprus; most significant is the group of miniature bronze weapons placed on top of the ashlar wall and sealed by mudbrick in the final reconstruction of room 10 in the Ashlar Building at Enkomi, Level IIIB. ${ }^{152}$ Although several bronze hoards have been identified in LC contexts, some of which might be considered as votive/cult deposits associated with some religious ceremony, ${ }^{153}$ current evidence indicates that the LC communities primarily chose to dispose of their valuables within the mortuary domain, ${ }^{154}$ rather than within structured foundation rituals. As such, the evidence from Aredhiou might highlight an aspect of ceremonial activity hitherto largely unrecognized in LC settlements.

In contrast to the foundation deposits from the Near East, the Aredhiou deposit stands out for its simplicity (comprising a single, incomplete Plain ware water jug) and its association with a nonelite, non-ceremonial structure, albeit one of economic importance. Joanna Smith identifies two possible Late Bronze Age foundation deposits placed in pits at Kition, in Temenos A and the 
adjacent Temple 5. The contents of these pits reflect the apparent simplicity of the Aredhiou deposit, comprising a group of figurines in the former and a range of everyday objects (loom and fishing weights, two juglets and a bowl, as well as a wall bracket fragment) in the latter. ${ }^{155}$ As with the jug from Aredhiou (and also the quern discussed above), the foundation objects from Kition were of a type that were commonly used within daily life in LC communities, suggesting a focus on daily praxis and social reproduction in the ritual performance. A modest foundation deposit from Protopalatial Malia, a single "teapot" placed in a stone cist, ${ }^{156}$ similarly provides close parallels to the Aredhiou deposit. Perhaps our jug was used to pour libations to commemorate the construction of the building, as has also been suggested for the Malia deposit; ${ }^{157}$ its incomplete state might equally illustrate part of the ritual, being deliberately broken before deposition. This relates closely to John Chapman's fragmentation theory, an approach that presupposes the deliberate, ritualized destruction and structured disposal of "special purpose objects" as part of their life-cycle; some objects indeed might be made specifically to be broken within ritual performance. The production, exchange, possession and eventual destruction of socialized objects create a symbiotic relationship between people and things and Chapman argues that the acts of destruction and deposition of the fragmented object reiterates this relationship; it "stands not only for the rest of the artefact but both persons concerned with the exchange". ${ }^{158}$ Once this relationship is established the object needs to be removed from future interactions, the obvious solution being its ritual destruction and deposition. ${ }^{159}$ Rather than the ad-hoc removal of a vessel that was no longer of any use, I would argue that the breaking and burial of the Plain ware jug represents a coherent stage in its biography ${ }^{160}$ and moreover gives us a glimpse into the ritualized performances of the community at Aredhiou. Even so, we might consider other scenarios: a builder using his broken water jug to shore up the shuttering of mortar, or choosing to place a simple memento of 
personal rather than cultural significance, much as builders to this day still leave mementos, such as coins, in walls. ${ }^{161}$

\section{CONCLUSIONS}

Excavations at Aredhiou give an intriguing insight into the otherwise unknown social worlds of a Late Bronze Age farming community. The diversity of activities at Aredhiou is unexpected: "industrial", some form of processing, maybe metallurgical, agricultural and storage. This contrasts with the better known single-activity production sites such as Sanidha Moutti tou Ayiou Serkhou (pottery) and Politiko Phorades (copper extraction). Examining these activities as part of a highly structured socialized world and attempting to recognize the people behind the archaeological record, allows us to develop a more holistic understanding of the LC economy. Many production activities carried out in the hinterland were no doubt seasonal and were arranged around the agricultural seasons. Members of the community at Aredhiou were surely involved in certain of these other production activities, suggesting even stronger ties between mining and farming settlements of the interior than has hitherto been posited; also seasonality and mobility of population have significant implications for the gender relations at sites such as Aredhiou. Certainly Aredhiou, and probably other similar sites such as Ayia Irini, provided a nodal point within its regional landscape, not only for agricultural, storage, and other activities, but also ceremonial practices and ritual performance. The site was also intrinsically integrated within a wider economic network with the coastal centers, as is demonstrated by access to imported commodities and occasional use of writing systems. There is also evidence for some form of control expressed physically by the investment in the architecture of Buildings 1 and 2, the organization of communal activities, which was mediated through ceremonial performance on the part of a select group of the community, analogous perhaps with Ayia Irini. In many respects therefore this agricultural production site merges squarely with the criteria Knapp set 
forward for secondary and tertiary centers. Although many questions remain, it is hoped that future work at Aredhiou Vouppes will throw further light on the habitus of this rural community.

\section{LIST OF FIGURES}

Fig. 1. Map of Cyprus (drawing by L. Steel).

Fig. 2. Plan of Aredhiou Vouppes (Lithosouros) (drawing by S. Thomas).

Fig. 3 Gaming stone found in survey in 2008 (photo by S. Thomas).

Fig. 4 Bronze Age wall eroding out of scarp (photo by S. Thomas).

Fig. 5. Ground stone anvil, surface find (photo by S. Thomas).

Fig. 6. Black Slip Jug, Aredhiou Vouppes Tomb 1 (drawing by A. South).

Fig. 7. Spear, Aredhiou Vouppes Tomb 1 (drawing by A. South).

Fig. 8. Entrance into Building 1, photo taken from east baulk. (photo by S. Thomas).

Fig. 9. Plan of Building 2 (drawing by L. Steel).

Fig. 10. Room 95, Building 2, photo taken from east (photo by S. Thomas).

Fig. 11. Plan of Building 1 (drawing by L. Steel).

Fig. 12. Wall bracket scoop, room 103 (photo by S. Thomas)

Fig. 13. Loomweight from Building 2 (photo by S. Thomas)

Fig. 14. Senet gaming stone, Building 1 (drawing by A. South).

Fig. 15. Foundation deposit in Building 2 (photo by S. Thomas).

\section{TABLE CAPTIONS}

Table 1. Relative Chronological Phases on Cyprus (after Crewe 2007b, table 1).

\section{WORKS CITED}

Allen, L.H. 2008. “The Gaming Stones of Arediou-Vouppes: Exploring the Past and Creating Identity through Material Remains.” MA diss., University of Wales Lampeter. 
Allison, P.M. 1999. "Introduction," in The Archaeology of Household Practices: Dwelling in the Past, edited by P.M. Allison, 1-18. London, New York: Routledge.

Amiry, S. and V. Tamari 1989. The Palestinian Village Home. London: British Museum. Åström, P. 1998. Hala Sultan Tekke 10. The Wells. SIMA XLV:10. Jonsered: P. Åströms Förlag.

Bolger, D. 1966. "Figurines, Fertility, and the Emergence of Complex Society in Prehistoric Cyprus." CurrAnthr 37: 365-73.

—.2003. Gender in Ancient Cyprus: Narratives of Social Change on a Mediterranean Island. Walnut Creek: Altamira Press.

Boulotis, C. 1982. “Ein Gründungsdepositum im minoischen Palast von Kato Zakros: minoischmykenische Bauopfer.” ArchKorrBl 12: 153-66.

Bourdieu, P. 1966. "The Sentiment of Honour in Kabyle Society." In Honour and Shame: The Values of Mediterranean Society, edited by in J. Peristany, 191-242. Chicago: University of Chicago Press.

— 1977. Outline of A Theory of Practice. Translated by R. Nice. Cambridge: Cambridge University Press.

Brock, R. 1994. "The Labour of Women in Classical Athens.” CQ 44: 336-46.

Budin, S.L. 2011. Images of Woman and Child from the Bronze Age: Reconsidering Fertility, Maternity and Gender in the Ancient World. Cambridge : Cambridge University Press.

Catling, H.W. 1962. "Patterns of Settlement in Bronze Age Cyprus." OpAth 4: 129-69.

—. 1976. “The Phlamoudhi Survey Again.” RDAC: 29-34.

Caubet, A., and M. Yon 1974. "Deux appliques murales Chypro-Géométriques au Louvre.” RDAC: $112-31$.

Chapman, J. 2000. Fragmentation in Archaeology: People, Places and Broken Objects in the Prehistory of South Eastern Europe. London and New York: Routledge. 
Cohen, D. 1989. "Seclusion, Separation, and the Status of Women in Classical Athens." GaR 36: 3-15.

Cole, S.G. 2004. Landscape, Gender and Ritual Space: The Ancient Greek Experience.

Berkeley: University of California Press.

Crewe, L. 2007a. Early Enkomi: Regionalism, Trade and Society at the Beginning of the Late

Bronze Age on Cyprus. BAR International Series 1706. Oxford: Archaeopress

_ 2007b. "Sophistication in Simplicity: The First Production of Wheelmade Pottery on Late Bronze Age Cyprus.” JMA 20: 209-38.

_.2009. "Regionalism and the First Appearance of Plain White Handmade Ware in the Middle Cypriot Bronze Age." In The Formation of Cyprus in the Second Millennium B.C.: Studies in Regionalism during the Middle and Late Bronze Ages, edited by I. Hein, 79-90. Vienna: Austrian Academy of Sciences Press.

Crewe, L. and I. Hill. 2012. "Finding Beer in the Archaeological Record: A Case Study from Kissonerga-Skalia on Bronze Age Cyprus.” Levant 44(2): 205-37.

Davis, J. 1977. People of the Mediteranean: An Essay in Comparative Social Anthropology. London, Henley and Boston: Routledge.

Dikaios, P. 1969-1971. Enkomi. Excavations 1948-1958. Mainz am Rhein: Verlag Philipp von Zabern.

Dolfini, A. 2013. "The Gendered House: Exploring Domestic Space in Late Italian Prehistory.” JMA 26: 131-57.

Du Plat Taylor, J. 1952. “A Late Bronze Age Settlement at Apliki, Cyprus” AntJ 32: 133-67. Ellis, R. 1968. Foundation Deposits in Ancient Mesopotamia. New Haven and London: Yale University Press. 
Fendin, T. 2006. “Grinding Processes and Reproductive Metaphors.” In Old Norse Religion in Long-Term Perspectives: Origins, Changes and Interactions, edited by A. Andrén, K. Jennbert and C. Raudvere, 159-63. Lund: Nordic Academic Press.

Fisher, K.D. 2014. "Rethinking the Late Cypriot Built Environment: Households and Communities as Places of Social Transformation." In The Cambridge Prehistory of the Bronze and Iron Age Mediterranean, edited by A.B. Knapp and P. van Dommelen, 399-416.

Cambridge: Cambridge University Press.

Frankel, D. and J.M. Webb 2001. "Population, Households, and Ceramic Consumption in a Prehistoric Cypriot Village.” JFA 28: 115-29.

—. 2012. "Household Continuity and Transformation in a Prehistoric Cypriot Village.” In New Perspectives on Household Archaeology, edited by B.J. Parker and C.P. Foster, 473-500. Winona Lake: Eisenbrauns.

Gell, A. 1998. Art and Agency: An Anthropological Theory, Oxford: Clarendon Press.

Given, M. 2002. Sydney Cyprus Survey Project 1992-1999. Glasgow: University of Glasgow.

Given, M. and A.B. Knapp 2003. The Sydney Cyprus Survey Project. Social Approaches to Regional Survey. Monumenta Archaeologica 21. Los Angeles: Cotsen Institute of Archaeology, University of California.

Gjerstad, E. 1926. Studies on Prehistoric Cyprus. Uppsala: Uppsala Universitet.

Gjerstad, E., J. Lindros, E. Sjöqvist and A. Westholm 1935. Swedish Cyprus Expedition II.

Finds and Results of the Excavations in Cyprus 1927-1931. Stockholm: Swedish Cyprus Expedition.

Goren, Y., S. Bunimovitz, I. Finkelstein and N. Na'aman 2003. "The Location of Alashiya: New Evidence from Petrographic Investigation of Alashiyan Tablets.” AJA 107: 233-55.

Herva, V.-P. 2005. “The Life of Buildings: Minoan Building Deposits in an Ecological Perspective." OJA 24: 215-27. 
Hodder, I. 2012. Entangled: An Archaeology of the Relationships between Humans and Things. Oxford: Wiley-Blackwell.

Horowitz, M.T. 2008. "Phlamoudhi-Vounari: A Multi-Function Site in Cyprus." In Views from Phlamoudhi, edited by J.S. Smith, 70-85. Boston: American Schools of Oriental Research. Hoskins, J. 1998. Biographical Objects: How Things Tell the Stories of People's Lives. New York and London: Routledge.

Isbell, W.H. 2000. "What Should We Be Studying: the Natural Community and the Imagined Community." In The Archaeology of Communities: a New World Perspective, edited by M.A. Cannuto and J. Yaeger, 243-66. London and New York: Routledge.

Karageorghis, V. 1965. “A Late Cypriot Tomb at Tamassos.” RDAC: 11-29.

Karageorghis, V. 1993. The Coroplastic Art of Ancient Cyprus. Late Cypriote II - CyproGeometric III. Nicosia: Leventis Foundation.

Karageorghis, V. \& M. Demas 1984. Pyla-Kokkinokremos. A Late 13th Century B.C. Fortified Settlement in Cyprus. Nicosia: Department of Antiquities.

1985. Excavations at Kition The Pre-Phoenician Levels. Areas I and II. Vol. V, pt. 1.

Nicosia: Department of Antiquities.

Karageorghis, V. and V. Kassianidou 1999. "Metalworking and Recycling in Late Bronze Age Cyprus - the Evidence from Kition.” OJA 18: 171-88.

Kassianidou, V. 2007. “Ground Stone Tools from Apliki Karamallos.” In Joan du Plat Taylor's Excavations at the Late Bronze Age Mining Settlement at Apliki Karamallos, edited by B. Kling and J.D. Muhly, 277-306. SIMA 134:1. Sävedalen: P. Åströms Förlag.

Keswani, P.S. 1989a. "Dimensions of Social Hierarchy in Late Bronze Age Cyprus: An Analysis of the Mortuary Data from Enkomi." JMA 2: 49-86. 
1989b. “The Pithoi and Other Plain Ware Vessels.” In Kalavasos-Ayios Dhimitrios, II.

Ceramics, Objects, Tombs, Specialist Studies, edited by A.K. South, P. Russell and P.S.

Keswani, 12-21. SIMA LXXI:3. Göteborg: P. Åströms Förlag.

1993. "Models of Local Exchange in Late Bronze Age Cyprus.” BASOR 292: 73-83.

1996. "Hierarchies, Heterarchies, and Urbanisation Process: the View from Bronze Age

Cyprus." JMA 9: 211-50.

—. 2004. Mortuary Ritual and Society in Bronze Age Cyprus. Monographs in Mediterranean Archaeology. London and Oakville: Equinox.

—. 2009. "Exploring Regional Variation in Late Cypriot II-III Pithoi: Perspectives from Alassa and Kalavasos." In The Formation of Cyprus in the Second Millennium B.C.: Studies in Regionalism during the Middle and Late Bronze Ages, edited by I. Hein, 107-25. Vienna:

Austrian Academy of Sciences Press.

Keswani, P.S. and A.B. Knapp 2004. "Bronze Age Boundaries and Social Exchange in NorthWest Cyprus.” OJA 22: 213-23.

Kling, B. 2007. “Other Objects from Apliki Karamallos.” In Joan du Plat Taylor's Excavations at the Late Bronze Age Mining Settlement at Apliki Karamallos, edited by In B. Kling and J.D. Muhly, 307-20. SIMA CXXXIV:1. Sävedalen: P. Åströms Förlag.

Knapp, A.B. 1988. “Hoards d'Oeuvres: Of Metals and Men on Bronze Age Cyprus.” OJA 7: $147-76$.

1997. The Archaeology of Late Bronze Age Cypriot Society: the Study of Settlement, Survey and Landscape. Glasgow: University of Glasgow.

—. 2003. "The Archaeology of Community on Bronze Age Cyprus: Politiko-Phorades in Context." AJA 107: 559-80.

-2008. Prehistoric and Protohistoric Cyprus. Identity, Insularity, and Connectivity.

Oxford: Oxford University Press. 
_ 2009. "Representations: Female Figurines and Social Identity on Protohistoric Cyprus." In Medelhavsmuseet: Focus on the Mediterranean, no. 5. Proceedings from the International Conference "Finds and Results from the Swedish Cyprus Expedition 1927-1931: A Gender Perspective," March 31-April 2, 2006. 137-44. Stockholm: Medelhavsmuseet - 2013a. The Archaeology of Cyprus: From Earliest Prehistory through the Bronze Age. Cambridge: Cambridge University Press.

_.2013b. "Revolution within Evolution: the Emergence of a 'Secondary State' on Protohistoric Bronze Age Cyprus.” Levant 45(1): 19-44.

_ 2013c. "Social Approaches to the Archaeology and Anthropology of Mining." In Social Approaches to the Industrial Past: the Archaeology and Anthropology of Mining, edited by E.W. Herbert, A.B. Knapp and V.C. Piggott, 1-23. New York: Routledge.

Knapp, A.B., S. Held, I. Johnson and P.S. Keswani 1994. "The Sydney Cyprus Survey Project (SCSP) - second preliminary season (1993).” RDAC: 329-43.

Knapp, A.B. and V. Kassianidou 2008. “The Archaeology of Late Bronze Age Copper Production. Politiko Phorades on Cyprus.” Anatolian Metal 4: 135-47.

Knapp, A.B., V. Kassianidou and M. Donnelly 2002. "Excavations at Politiko-Phorades: A Bronze Age Copper Smelting Site on Cyprus.” Antiquity 76: 319-20.

Knappett, C., V. Kilikoglou, V. Steel and B. Stern 2005. "The Circulation and Consumption of Red Lustrous Wheelmade Ware: Petrographic, Chemical and Residue Analysis. AnatSt 55: 2559.

Koehl, R.B. 2005. Aegean Bronze Age Rhyta. Philadelphia: INSTAP Academic Press.

Kopytoff, I. 1986. “The Cultural Biography of Things: Commoditization as Process.” In The Social Life of Things Commodities in Cultural Perspective, edited by A. Appadurai, 64-91. Cambridge: Cambridge University Press. 
LaMotta, V.M. and M.B. Schiffer 1999. "Formation Processes of House Floor Assemblages." In The Archaeology of Household Activities, edited by P.M. Allison, 19-29. London, New York: Routledge.

Last, J. 2005. “Art.” In Çatalhöyük Perspectives: Reports from the 1995-99 Seasons, edited by I. Hodder, 197-208. Çatalhöyük Research Project Volume 6. BIAA Monograph 40.

Lidström Holmberg, C. 2004. "Saddle Querns and Gendered Dynamics of the Early Neolithic in Mid Central Sweden." In Coast to Coast-Arrival. Results and Reflections. Proceedings of the Final Coast to Coast Conference 1-5 October 2002 in Falköping, Sweden. Coast to Coast book No. 10, edited by H. Knutson, 199-231. Uppsala: Uppsala University.

London, G.A. 2002. "Women Potters and Craft Specialization in a Pre-Market Cypriot Economy." In Engendering Aphrodite: Women and Society in Ancient Cyprus, edited by D.

Bolger and N. Serwint, 265-75. CAARI Monographs 3. Boston: American Schools of Oriental Research.

Maier F.G. 1997. “The Mycenaean Pottery of Palaipaphos Reconsidered.” In Proceedings of the International Archaeological Conference "Cyprus and the Aegean in Antiquity, from the Prehistoric Period to the 7th Century A.D. ”, 93-102. Nicosia, Department of Antiquities, Cyprus.

Maran, J. 2004. "The Spreading of Objects and Ideas in the Late Bronze Age Eastern Mediterranean: Two Case Examples from the Argolid of the 13th and 12th Centuries B.C." BASOR 336: 11-30.

Masson, O. 1964. “Kypriaka I. Recherches sur les antiquités de Tamassos.” BCH 88, 199-238. Meyers, C. 1998. Discovering Eve: Ancient Israelite Women in Context. New York: Oxford University Press.

—. 2003. "Women's Culture in Agrarian Households of the Iron Age." In Symbiosis, Symbolism, and the Power of the Past: Canaan, Ancient Israel, and Their Neighbors from the 
Late Bronze Age through Roman Palaestina, edited by W.G. Dever and S. Gitin, 425-44.

Winona Lake Indiana: Eisenbrauns.

Museum of London Archaeological Service 1994. Archaeological Site Manuel. $3^{\text {rd }}$ edn.

London: Museum of London.

Nanoglou, S. 2008. "Building Biographies and Households: Aspects of Community Life in Neolithic Northern Greece.” Journal of Social Archaeology 8: 139-59.

Öbrink U. 1979. Hala Sultan Tekke 6. A Sherd Deposit in Area 23. SIMA XLV: 6, Göteborg: P. Åströms Förlag.

Papaconstantinou, D. 2002. "Life Cycles and the Dynamics of Domestic Architecture:

Households in Neolithic Cyprus.” In Engendering Aphrodite: Women and Society in Ancient Cyprus, edited by D. Bolger and N. Serwint, 33-51. CAARI Monographs 3. Boston: American Schools of Oriental Research.

Paz, S. 2012. "Changing Households at the Rise of Urbanism: the EB I-II Transition at Tel Bet Yerah.” In New Perspectives on Household Archaeology, edited byB.J. Parker and C.P. Foster, 407-34. Winona Lake: Eisenbrauns.

Pelon, O. 1986. "Un dépôt de foundation au palais de Malia.” BCH 110: 3-19.

Peltenburg, E.J. 1996. “From Isolation to State Formation in Cyprus, c.3500-1500 BC.” In The Development of the Cypriot Economy from the Prehistoric Period to the Present Day, edited by V. Karageorghis and D. Michaelides, 17-43. Nicosia, Leventis Foundation.

Pilides, D. 1996. "Storage Jars as Evidence of the Economy of Cyprus in the Late Bronze Age." In The Development of the Cypriot Economy from the Prehistoric Period to the Present Day, edited by V. Karageorghis and D. Michaelides, 107-26. Nicosia: Leventis Foundation. Russell P. 1989. “The Fine Ware Ceramics: the Settlement Deposits in the West, Central, East and South-East Areas.” In Kalavasos-Ayios Dhimitrios, II. Ceramics, Objects, Tombs, 
Specialist Studies, edited by A.K. South, P. Russell and P.S. Keswani, 1-11. SIMA LXXI:3, Göteborg: P. Åströms Förlag.

Schaeffer, C.F.A. 1969. Ugaritica VI. Mission de Ras Shamra 17. Paris: Editions Boccard. Schlipphak, R. 2001. Wandappliken der Spätbronze- und Eisenzeit im östlichen

Mittelmeerraum. Abhandlungen des Deutschen Palastinavereins 28. Wiesbaden: Harassowitz. Shott, A.S. 1996. "Mortal Pots: On Use Life and Vessel Size in the Formation of Pottery Assemblages.” AmerAnt 61: 463-82.

Smith, D.C. 2011. "The Context of Wall Brackets during the Late Bronze Age on Cyprus." MA diss, School of Historical Studies, University of Melbourne.

Smith, J.S. 1994. Seals for Sealing in the Late Bronze Age. PhD diss., Bryn Mawr College —. 2002. "Changes in the Workplace: Women and Textile Production on Late Bronze Age Cyprus.” In Engendering Aphrodite: Women and Society in Ancient Cyprus, edited by D. Bolger and N. Serwint, 281-312. CAARI Monographs 3. Boston, American Schools of Oriental Research.

—. 2008. "Settlement to Sanctuary at Phlamoudhi-Melissa." In Views from Phamoudhi, Cyprus, edited by J.S. Smith, 45-69. Boston: American Schools of Oriental Research.

2009. Art and Society in Cyprus from the Bronze Age into the Iron Age.

Cambridge: Cambridge University Press.

South, A.K. 1999. “A Fishy Stirrup Jar and More about Aegean Connections at Kalavasos.” In Studies in Aegean Archaeology Presented to Malcolm Wiener as He Enters His 65th Year, edited by P. Betancourt, R. Laffineur, V. Karageorghis. Aegaeum 20: 793-802.

South, A.K., Russell, P. and Keswani, P.S. 1989. Kalavasos-Ayios Dhimitrios II. Ceramics, Objects, Tombs, Specialist Studies. SIMA LXXI:3, Göteborg. P. Åströms Förlag. 
South, A.K. and P. Russell 1993. "Mycenaean Pottery and Social Hierarchy at Kalavasos-Ayios Dhimitrios, Cyprus.” In Proceedings of the International Conference “Wace and Blegen: Pottery as Evidence for Trade in the Aegean Bronze Age, 1939-1989”, edited by C. Zerner, 303-10. Amsterdam: J.C. Gieben.

South, A.K. and L. Steel 2007. "Red Lustrous Wheelmade Ware from Kalavasos." In The Lustrous Wares of Late Bronze Age Cyprus and the Eastern Mediterranean, edited by I. Hein, 179-90. Vienna: Austrian Academy of Sciences Press.

Souvatzi, S.G. 2008. A Social Archaeology of Households in Neolithic Greece: An Anthropological Approach. Cambridge: Cambridge University Press.

Steel, L. 2004. “A Reappraisal of the Distribution, Context and Function of Mycenaean Pottery in Cyprus." In La Céramique Mycénienne de l'Égée au Levant. Hommage à Vronwy Hankey, edited by J. Balensi, J.-Y. Monchambert, S. Müller-Celka, 69-85. Travaux de la Maison de l’Orient et de la Méditerranée. Lyon: Editions Boccard.

—. 2009. "Exploring Regional Settlement on Cyprus in the Late Bronze Age: the Rural Hinterland." In The Formation of Cyprus in the Second Millennium B.C.: Studies in Regionalism during the Middle and Late Bronze Ages, edited by I. Hein, 135-45. Vienna: Austrian Academy of Sciences Press.

_.2013a. Materiality and Consumption in the Bronze Age Mediterranean. New York and London: Routledge.

_.2013b. "The Social World of Early-Middle Bronze Age Cyprus: Rethinking the Vounous Bowl." JMA 26(1): 51-73.

Steel, L. and S. Janes 2005. "Survey at Arediou-Vouppes, Cyprus.” RDAC: 231-44.

Steel, L. and C. McCartney 2008. "Survey at Arediou Vouppes (Lithosouros): A Late Bronze Age Agricultural Settlement on Cyprus. A Preliminary Analysis of the Material Culture Assemblages.” BASOR 351: 9-37. 
Steel, L. and S. Thomas 2008. "Excavations at Arediou-Vouppes (Lithosouros), Cyprus. An Interim Report on Excavations 2005-2006.” RDAC: 227-49.

Stockhammer, P.W. 2011. “An Aegean Glance at Megiddo.” In Our Cups are Full: Pottery and Society in the Aegean Bronze Age. Papers Presented to Jeremy B. Rutter on the Occasion of his 65th Birthday, edited by W. Gauß, M. Lindblom, R. Angus K. Smith and J.C. Wright, 282-96. Oxford: Archaeopress.

—. 2012. "Performing the Practice Turn in Archaeology." Transcultural Studies 1: 7-42. http://archiv.ub.uni-heidelberg.de/ojs/index.php/transcultural/article/view/9263/3238

Swiny, S. 1986. "The Lithic Industry of Episkopi Phaneromeni and Pre-Late Cypriot sites in the region." In The Kent State University Expedition to Episkopi Phaneromeni, Part 2, edited by S. Swiny, 1-65. SIMA LXXIV pt. 2, Göteborg: . P. Åströms Förlag.

—. 2003. “The Ground Stone.” In Sotira Kaminoudhia: An Early Bronze Age Site in Cyprus, edited by S. Swiny, G. Rapp and E. Herscher, 221-87. CARRI Monograph Series 4. Boston: ASOR.

Taylor, E.L. 1996. “Kafeneia: a Case Study of Family Alienation.” International Journal of Sociology of the Family 26(1): 107-14.

Tringham, R. 1991. "Households with Faces: the Challenge of Gender in Prehistoric Architectural Remains.” In Engendering Archaeology, edited by J. Gero, J. and M. Conkey 93131. Oxford: Blackwell.

Varien, M.D. and M. Potter 1997. "Unpacking the Discard Equation: Simulating the Accumulation of Artifacts in the Archaeological Record.” AmerAnt 62: 193-213.

Vermeule, E. and F. Wolsky 1990. Toumba tou Skourou: A Bronze Age Potter's Quarter on Morphou Bay. Boston: Harvard University Press.

Webb, J.M. 2002. "Engendering the Built Environment: Household and Community in Prehistoric Bronze Age Cyprus." In Engendering Aphrodite: Women and Society in Ancient 
Cyprus, edited by D. Bolger and N. Serwint 87-101. CAARI Monographs 3. Boston: American Schools of Oriental Research.

—. 2009. "Keeping House: Our Developing Understanding of the Early and Middle Cypriot Household (1926-2006).” In Medelhavsmuseet: Focus on the Mediterranean, no. 5.

Proceedings from the International Conference "Finds and Results from the Swedish Cyprus Expedition 1927-1931: A Gender Perspective," March 31-April 2, 2006. 255-67. Stockholm: Medelhavsmuseet.

—. 2012: “Kalopsidha: 46 years after SIMA Volume II.” In J.M. Webb \& D. Frankel (eds) Fifty Years On. SIMA's Contribution to Cypriot Archaeology. 49-58. SIMA CXXXVII. Uppsala: Paul Åströms Förlag.

Webb, J.M. and D. Frankel 1994. "Making an Impression: Storage and Surplus Finance in Late Bronze Age Cyprus.” JMA 7: 5-26.

Weinstein, J. 1973. "Foundation Deposits in Ancient Egypt.” PhD diss., University. of Pennsylvania.

Wilk, R.R. and Rathje, W.L. "Household Archaeology." The American Behavioral Scientist 25: 617-39.

Yaeger, J and M.A. Canuto 2000. "Introducing an Archaeology of Communities.” In The Archaeology of Communities: A New World Perspective, edited by M.A. Cannuto and J. Yaeger 1-15. London and New York: Routledge.

Yasur-Landau, A. 2005. ““'Old Wine in New Vessels: Intercultural Contact, Innovation and Aegean, Canaanite and Philistine Foodways.” TelAviv 32(2):168-91.

* I would like to thank Steve Thomas for his continued support and encouragement for fieldwork at Aredhiou, the photography and for reading preliminary drafts of this paper. Also I 
am indebted to colleagues from the School of Archaeology, History and Anthropology, University of Wales Trinity Saint David for their helpful comments made in a seminar presentation of this paper. The insightful comments of my reviewers have helped to refine the arguments presented in this paper. Thanks also to Alison South for preparation of the finds drawings. Fieldwork at Aredhiou has only been possible with the support of the Department of Antiquities, in particular Dr Pavlos Flourentzos, Dr Despo Pilides, and Dr Eftychia Zachariou, and the dedicated work by the team of students from the University of Wales, Lampeter. Above all I would like to thank Andreas Petevenos and Ioannis Ioannou (the previous and current koinotarchis of Aredhiou), Papa Petros Photiou, Maria Vasileios, and all the villagers of Aredhiou for their warm welcome and ongoing support for the project.

${ }^{1}$ Crewe 2007b, 213-14; Knapp 2008, 134-6; Knapp 2013a, 348-9.

${ }^{2}$ Goren et al. 2003; Knapp 2003, 560.

${ }^{3}$ See however, Fisher's recent discussion (2014) of household practices within the Late Cypriot urban environment.

${ }^{4}$ See for example Frankel and Webb 2001; 2012; Webb 2002; 2006.

${ }^{5}$ See for example Smith 1994; Keswani 1996; Peltenburg 1996; most recently Knapp 2013 b. ${ }^{6}$ Webb and Frankel 1994.

${ }^{7}$ Gjerstad et al. 1935, 667-8, 820-1. Ayia Irini was identified by Gjerstad as a rural sanctuary and dated to LC III; however the ritual function was largely extrapolated from the later Iron Age sanctuary at the site. Instead, analogy between the architectural remains and the recorded finds suggest an agricultural rather than a -ritual function and also a LC IIC date. This need not preclude some ritual element to activities performed at the site, an aspect which we have also explored at Aredhiou, see discussion below.

${ }^{8}$ Catling 1962; Keswani 1993; 1996; Knapp 1997; see also Knapp and Kassianidou 2008.

${ }^{9}$ Catling 1962. 
${ }^{10}$ Keswani 1993.

${ }^{11}$ Knapp 1997; 2013b, 32.

12 Tringham 1991, 94.

13 Tringham 1991; Papaconstantinou 2002; Webb 2002; Nanoglou 2008. For a detailed discussion of the household, kinship, co-residency, productions, consumption, the house, and social reproduction see Souvatzi 2008, 7-31.

${ }^{14}$ Yaeger and Canuto 2000; Isbell 2000; Knapp 2003.

${ }^{15}$ They reproduce themselves socially through the vertical transmission of knowledge down the generations, as exemplified by Bourdieu's (1977) notion of habitus. See also Allison 1999, 1.

${ }^{16}$ Yaeger and Canuto 2000, 2-4; Isbell 2000, 243.

${ }^{17}$ Yaeger and Canuto 2000, 4.

${ }^{18}$ Yaeger and Canuto 2000, 11; Isbell 2000, 249.

${ }^{19}$ Papaconstantinou 2002, 36.

${ }^{20}$ See discussion in Frankel and Webb 2012, 479-80 for example. Also Fisher's analysis of space and social action in the LC urban landscape.

${ }^{21}$ Museum of London Archaeological Service 1994.

${ }^{22}$ Frankel and Webb 2012, 479.

${ }^{23}$ Frankel and Webb 2012, 479-80.

${ }^{24}$ Knapp et al. 1994, 337-8; Given and Knapp 2001, 179-82, 268; Steel and Janes 2005, 231.

${ }^{25}$ The name given by SCSP to the site was that visible on the 1923 cadastral for fields in the adjacent riverbed; during excavation the local farmers told us the locality name for the fields in which the site is located.

${ }^{26}$ See for example Catling 1976; Webb and Frankel 1994.

${ }^{27}$ Keswani 1993, 76; Knapp et al. 1994; Given 2002, 7; Given and Knapp 2003, 179-82.

${ }^{28}$ Keswani 1993, 79-80; Knapp and Kassianidou 2008, 147. 
${ }^{29}$ Steel and Janes 2005: Steel and McCartney 2008; Steel and Thomas 2008.

${ }^{30}$ Steel and McCartney 2008, 20-1, fig. 14.

${ }^{31}$ Steel and McCartney 2008, 15-16; Steel 2009, 139.

${ }^{32}$ Keswani 2009, 107.

${ }^{33}$ Steel and McCartney 2008, 30, fig. 22.

${ }^{34}$ Webb and Frankel 1994, 14-6.

${ }^{35}$ I am grateful to Carole McCartney for identifying flattened stones with pecked-out cup marks as probable anvils - the pecking resulting from repeated blows to the surface by a heavy pounding tool, probably for crushing copper ore. McCartney personal communication September 2012.

${ }^{36}$ Steel and Thomas 2008, 235, fig. 13; also some imported Levantine Red Slip Burnished ware was identified in excavations in 2008 .

${ }^{37}$ Steel and McCartney 2008, 16, 17, 19, table 1.

${ }^{38}$ Steel and McCartney 2008, 16.

${ }^{39}$ Pilides 1996, 108-9.

${ }^{40}$ Crewe 2009, fig. 3, pl. 1/7-9.

${ }^{41}$ Crewe 2009, 79-80.

${ }^{42}$ Smith 2008, 61-2; Horowitz 2008, 77.

${ }^{43}$ Steel and McCartney 2008, table 1, 17-18.

${ }^{44}$ Gjerstad 1926, 27-37.

${ }^{45}$ Bolger 2003, 35-6.

${ }^{46}$ Webb 2012, 52-3, fig. 5.

${ }^{47}$ Steel and Thomas 2008, fig. 26; Steel 2009, fig. 7.

${ }^{48}$ Crewe 2007b, 227.

${ }^{49}$ Crewe 2007b, 227-8. 
${ }^{50}$ Steel 2013a, 227.

${ }^{51}$ Masson 1964; Karageorghis 1965; Keswani 1989a, fig. 6.1; 2004, 143; Given and Knapp 2003, 268; Knapp and Kassianidou 2008, 147; Steel 2013a, 148-52.

${ }^{52}$ Knapp and Kassianidou 2008.

${ }^{53}$ Crewe 2007a.

${ }^{54}$ Vermeule and Wolsky 1990.

${ }^{55}$ Knapp 2009, 136.

${ }^{56}$ Steel and Thomas 2008; Steel 2009.

${ }^{57}$ Given the problems inherent in the estimation of population size from archaeological sites, and the still limited extent of the site excavated, it would be unwise and misleading at this stage to propose a population figure.

${ }^{58}$ Knapp 2013c, 4.

${ }^{59}$ Kassianidou 2007.

${ }^{60}$ The nature and extent of metallurgical activity at Aredhiou is currently being investigated by Lente van Brempt, University of Cyprus.

${ }^{61}$ London 2002, 271.

${ }^{62}$ Some pithos samples from Arediou are being analysed by Priscilla Keswani as part of an island-wide project examining pithos production on Cyprus.

${ }^{63}$ Davis $1977,38$.

${ }^{64}$ Steel and Thomas 2008.

${ }^{65}$ Steel 2009, 140, 142.

${ }^{66}$ Bolger 2003, 43-9 provides a clear overview of LC household organisation of space and activities at sites such as Kalavasos, Enkomi and Kourion. Fisher discusses the social use of space within the LC urban households, considering specific activities within discrete areas, the agency of the built environment, and habitus. Analysis of space and habitus at Aredhiou adds a 
further dimension to this discussion with the complementary observations of the rural dimension.

${ }^{67}$ Despite flotation of various deposits, in particular from pits, no meaningful botanical remains have been recovered from the site. The animal bones, primarily from deposits south of Building 2, are currently being analysed by Ros Coard, University of Wales Trinity Saint David.

${ }^{68}$ Steel and McCartney 2008.

${ }^{69}$ The pottery is currently being analysed by the author and results will be presented in the final publication of the site.

${ }^{70}$ Bourdieu 1966, 222; Cohen 1989, 7, 8, 10-11, 12; Brock 1994, 339, n. 16. This is discussed in more detail below.

${ }^{71}$ Öbrink 1979; Maier 1997, 101; Steel 2004.

${ }^{72}$ Bolger 2003, 49.

${ }^{73}$ A massive, square stone-lined well located within an open area, was excavated in Area B at Episkopi Bamboula; Weinberg 1983, 32, pl. 8a-d. While most wells at Hala Sultan Tekke Area were private, the excavators suggest that well F1620 was communal, with access from the street; Åström 1998, 133.

${ }^{74}$ Steel and Thomas 2008, fig. 29.

${ }^{75}$ Steel and Thomas 2008, fig. 31.

${ }^{76}$ Steel and Thomas 2008; Steel 2009, 142.

${ }^{77}$ Steel 2009, 139-40.

${ }^{78}$ Steel and Thomas 2008; Steel 2009, 139-40.

${ }^{79}$ Steel and Thomas 2008, fig. 16.

${ }^{80}$ Steel and McCartney 2008, fig. 18.

${ }^{81}$ Du Plat Taylor 1952, pl. XXVII.a1.

${ }^{82}$ Steel 2009, 140. 
${ }^{83}$ Kassianidou 2007, 278, 279, 281-3.

${ }^{84}$ Steel and Thomas 2008, 241, fig. 18; Steel 2009, 140.

${ }^{85}$ cf. Russell 1989, 6.

${ }^{86}$ cf. Keswani 1989b, fig. 16.2.

${ }^{87}$ Crewe and Hill 2012.

${ }^{88}$ Steel 2009, 140.

${ }^{89}$ Steel and Thomas 2008, fig. 18.

${ }^{90}$ Steel 2009, 140.

${ }^{91}$ Du Plat Taylor 1952, pl. XXVII.a5; Swiny 1986, fig. 17; South et al.1989, pl. XIV, K-AD

417; Kassianidou 2007, 280, pl. 76

${ }^{92}$ South and Russell 1993, 306; Steel 2004, 75.

${ }^{93}$ South 1999, 798-9.

${ }^{94}$ Schott 1996; Varien and Potter 1997; LaMotta and Schiffer 1999; see also discussion in Frankel and Webb 2001.

${ }^{95}$ Maran 2004, 16; Steel and McCartney 2008, 30; Smith 2011.

${ }^{96}$ Caubet and Yon 1974; Kling 2007, 307.

${ }^{97}$ Schlipphak 2001.

${ }^{98}$ Schlipphak 2001, 18-20, 46.

${ }^{99}$ Smith 2011.

${ }^{100}$ Dikaios 1969-1971, 731, 762.

${ }^{101}$ Karageorghis and Demas 1984, 10-12, 13-14.

${ }^{102}$ Schaeffer 1969, fig. 13.

${ }^{103}$ Stockhammer 2012, 23.

${ }^{104}$ Stockhammer 2012, 288.

${ }^{105}$ Stockhammer 2012, 22. 
${ }^{106}$ Steel 2013a, 33-5.

${ }^{107}$ Yasur-Landau 2005, 176; Stockhammer 2011, 289; Stockhammer 2012, 22-6.

${ }^{108}$ Smith 2009, 86-7.

${ }^{109}$ Knappett et al. 2005, 49.

${ }^{110}$ South and Steel 2007.

${ }^{111}$ Knappett et al. 2005, 49.

${ }^{112}$ Wilk and Rathje 1982.

${ }^{113}$ Allison 1999, 3.

${ }^{114}$ See discussion in Cohen 1989; Bolger 2003, 51-3; Meyers 1998; 2003.

${ }^{115}$ Davis $1977,22,38,43-5$.

${ }^{116}$ Cohen 1989, 12; Brock 1994, 342-4.

${ }^{117}$ Amiry and Tamari 1989, 34.

${ }^{118}$ Davis $1977,38$.

${ }^{119}$ Webb 2002; Frankel and Webb 2012, 491.

${ }^{120}$ Bolger 2003, 39.

${ }^{121}$ Meyers 2003, 430-4; for further discussion of female textile production see Barber 1991; Brock 1994, 339; Smith 2002.

${ }^{122}$ Amiry and Tamari 1989, 42-3.

${ }^{123}$ Karageorghis 1993, 62-4, 92, pls. XII/1-7, XLI/3. The possible ritual connotations of these objects is reflected by the merging of social and ritual aspects of water-carrying by unmarried girls, the hydrophoroi, in Classical Greece, discussed by Cole 2004, 45.

${ }^{124}$ Bolger 1996, 369; Bolger 2003, 115-7; Knapp 2009, 139; Budin 2011, 221, 229-45, 259-61, 264-6; Steel 2013a, 183, 217, 221-2; Steel 2013b, 54, 65, fig. 2c.

${ }^{125}$ Meyers 2003, 428-9, 435-6. 
${ }^{126}$ Similar to the organization of activity areas in household spaces in contemporary LC urban communities, as discussed by Fisher 2014.

${ }^{127}$ Dolfini (2013) discusses the daily performance of household activities in Final Bronze Age Italian villages; see also a recent analysis of Early Bronze Age Tel Bet Yerah, Paz 2012, 414; for a Cypriot parallel there is Frankel and Webb's detailed investigation into Early-Middle Bronze Age Marki Alonia, Frankel and Webb 2012, 491. Perhaps the best known Mediterranean ethnography for gendered spaces is Bourdieu's 1966 examination of the Kabyle village.

${ }^{128}$ Meyers 2003, 428.

${ }^{129}$ See Meyers 2003, 429.

${ }^{130}$ For example Meyers 1998; 2003; Webb 2002; Bolger 2003.

${ }^{131}$ Bourdieu 1966, 222.

${ }^{132}$ Meyers 2003, 428.

${ }^{133}$ Hoskins 1998; Kopytoff 1986; see also discussion in Steel 2013a, 191.

${ }^{134}$ Allen 2008. Walter Crist's wider analysis of Bronze Age gaming stones from Cyprus will help contextualize and undoubtedly enhance final analysis of the Aredhiou gaming stones.

135 Swiny 1986; 2003.

${ }^{136}$ Swiny 1986, 44.

${ }^{137}$ Swiny 1986, 47.

${ }^{138}$ See for example Taylor 1996.

${ }^{139}$ Hodder 2012. See for example Stockhammer 2012; Steel 2013a.

${ }^{140}$ Gell 1998.

${ }^{141}$ Last 2005, 205.

${ }^{142}$ Steel and McCartney 2008, 31, fig. 25.

${ }^{143}$ Steel and Thomas 2008, fig. 29; Steel, 2009, 142.

${ }^{144}$ Steel 2013a, 191, fig. 7.1. 
${ }^{145}$ Herva 2005, 224.

${ }^{146}$ Fendin 2006, 159; Lidström Holmberg 2004.

${ }^{147}$ Weinstein 1973.

${ }^{148}$ Ellis 1968.

${ }^{149}$ Boulotis 1982; Herva 2005; Koehl 2006, 332-3.

${ }^{150}$ Pelon 1986, 10; Herva 2005, 216-7.

${ }^{151}$ Koehl 2006.

${ }^{152}$ Dikaios 1969-71, 295-6.

${ }^{153}$ Knapp 1988, 155-6.

${ }^{154}$ Keswani 2004.

155 Smith 2009, 63, 64. There is some evidence for the continuation of such practices into the Iron Age at Kition, discussed in Smith 2009, 200, 201.

${ }^{156}$ Pelon 1986.

${ }^{157}$ Pelon 1986, 12.

${ }^{158}$ Chapman 2000, 37.

${ }^{159}$ Chapman 2000, 24-6.

${ }^{160}$ Chapman 2000; Herva 2005, 222-4.

${ }^{161}$ Steve Thomas, personal communication. 